Acta Horticulturae et Regiotecturae 1

Nitra, Slovaca Universitas Agriculturae Nitriae, 2018, pp. 13-16

\title{
THE YIELD OF SELECTED VARIETIES OF AMERICAN BLUEBERRY (VACCINIUM CORYMBOSUM L.) IN THE FIRST YEARS OF FRUITING IN THE WESTERN PART OF POLAND
}

\author{
Weronika MASŁOWSKA*, Daniel LIBERACKI \\ Poznań University of Life Sciences, Faculty of Environmental Engineering and Spatial Management, \\ Institute of Land Improvement, Environmental Development and Geodesy, Poland
}

\begin{abstract}
This paper presents the influence of meteorological conditions prevailing in the western part of Poland on the yield of selected blueberry varieties. The research was conducted on a small plantation located in the Przyczyna Górna village, in the Wschowa district of the Lubuskie province. There are five varieties of blueberry: Patriot, Duke, Chandler, Elliott and Bleuecrop. The studied years $2014,2015,2016$, as the first fruiting years, were presented in relation to the multi-year 2006-2016. The 2014 was the warmest year during this period with an average air temperature of $10.3^{\circ} \mathrm{C}$, whilst the lowest temperature was $7.6^{\circ} \mathrm{C}$ recorded in 2010 . The highest precipitation was in 2016, with the precipitation level of $760 \mathrm{~mm}$. However, the year with the lowest precipitation of $418 \mathrm{~mm}$ turned out to be 2011. The goal of the study in 2014-2016 was to evaluate the respective yields of five varieties of blueberry on a small plantation, taking into account various meteorological conditions.
\end{abstract}

Keywords: blueberry, precipitation, temperature, yield

For many years, Poland has been recognised as a leading European and world producer of blueberries. Continuous growing interest in and demand for its fruits have led to increased areas of growth. With the correct conditions for growth, it can fruit for 40 years, and even more (Kaiser et al., 2014). Plantations in Poland have brought high profits due to the favourable climatic conditions for the growth and yielding of blueberries. However, the high blueberry is a demanding plant and for optimal results it should be provided with optimal conditions for growth and fruiting. The blueberry requires specific soil parameters, such as a $\mathrm{pH}$ value of approximately 4.0 and adequate moisture (Pliszka, 2002). Humus content should be about 3.5\% (Eck, 1988). During the vegetation period, the groundwater level should be maintained at the levels of $0.35 \mathrm{~m}$ to $0.6 \mathrm{~m}$, depending on the type of soil (Smolarz, 2008).

One of the factors affecting the productivity of the crops is climate. Unfortunately, a number of unfavourable weather events have been reported in recent years. There has been an increase in the occurrence of atmospheric drought, especially during the growing season, as well as the occurrence of intense precipitation (Bokwa and Skowera, 2009).

This study was conducted on the influence of meteorological conditions prevailing in the western part of Poland on the yield of the selected blueberry varieties. The main task of the conducted research was to compare the yields of five selected blueberry varieties in the area of a small, home-grown plantations.

\section{Material and methods}

The subject of the research is located in the area of the Przyczyna Górna village. The village is located in the area of the Wschowa district within the municipality of Wschowa in the Lubuskie province. In the autumn of 2011, 150 bushes of blueberry were planted in the plantation. Because of a lack of adequate protection of the young seedlings from frost, a large part of plants was already frozen in the first year. This was consistent with the results obtained by Krzewińska (2009). The plants have grown in 11 rows of 7 bushes with a spacing of $3.0 \times 1.5 \mathrm{~m}$. The research was conducted on five varieties of blueberry: Patriot, Duke, Chandler, Elliott and Bleuecrop. The $\mathrm{pH}$ level before acidification was 6.0. One year before the plantation, the soil was acidified by sulfurization (Wigor S) at the dose of $12.0 \mathrm{~kg} .100 \mathrm{~m}^{-2}$, resulting in the change of $\mathrm{pH}$ level to $\mathrm{pH} 4.0$. In the later years, soil care was based on the use of sawdust mulching under each bush. Sawdust was scattered around the plants in the radius of 0.5-0.8 m, for the thickness of 0.03-0.05 m.

Fertilization of potassium and phosphorus was carried out before the plantation started. Later, phosphate and potassium fertilizers were mixed and sown mainly after harvesting fruit (Schönthaler et al., 2015). In the paperwork, we observed plant reaction of the used fertilizers and decided to use Substral's ready fertilizer mixes. The fertilizing dose was $10 \mathrm{~g} .100 \mathrm{~m}^{-2}$.

The plants were pruned once a year, after fruiting (Pliszka 2002). According to Kovaleski's research (2015) no pruning 


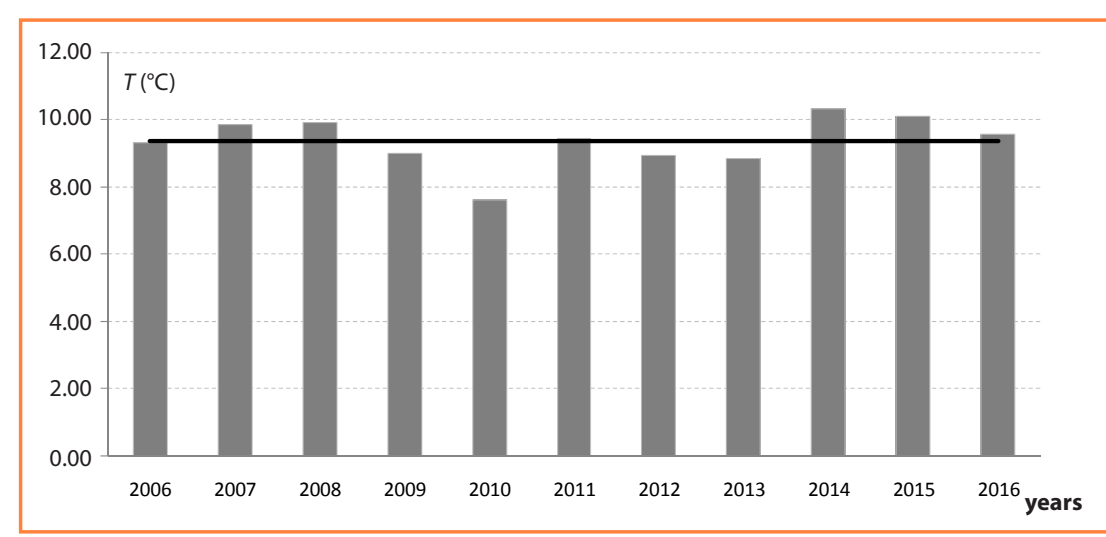

Fig. 1 Average annual air temperature on the average background of multiple years 2006-2016

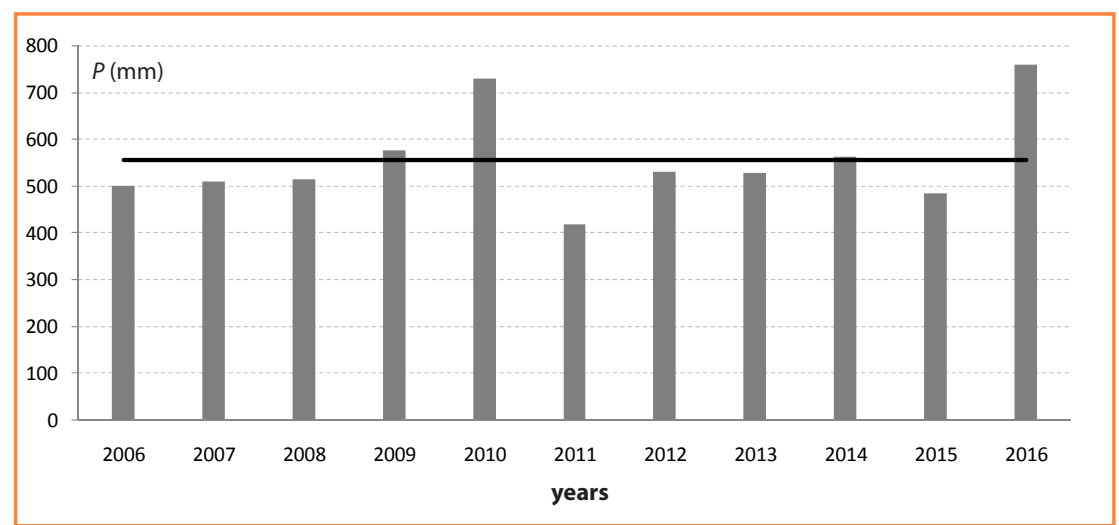

Fig. 2 Annual precipitation in the years 2006-2016

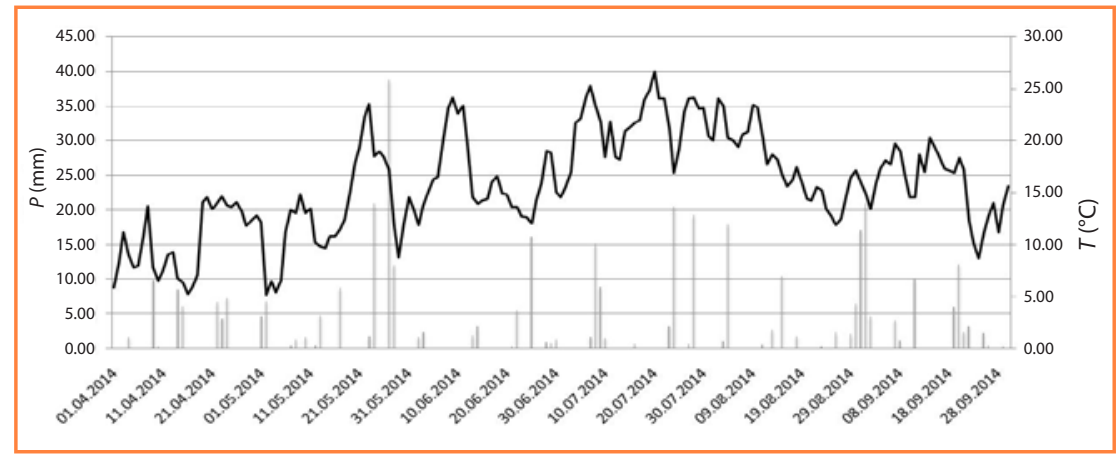

Fig. 3 Daily precipitation in $\mathrm{mm}$ and air temperatures in ${ }^{\circ} \mathrm{C}$ for 2014 , during the growing season of blueberries

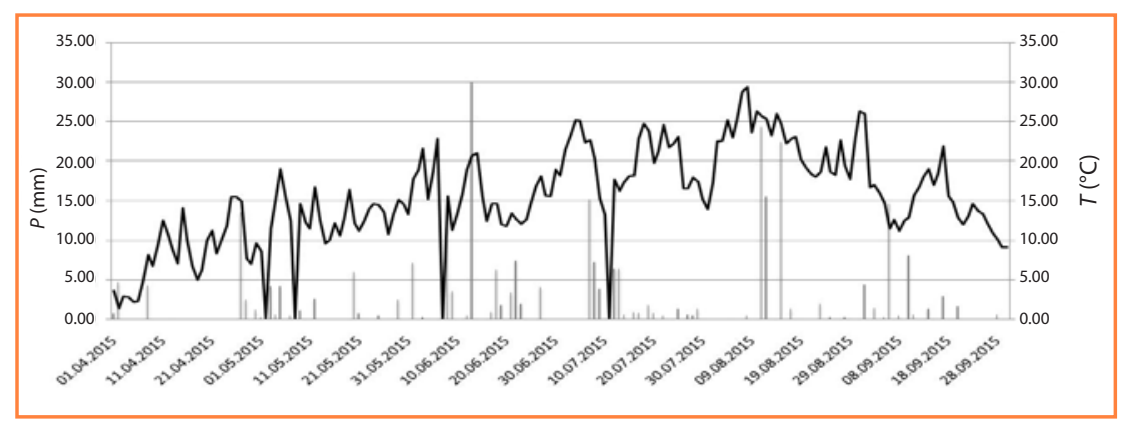

Fig. 4 Daily precipitation in $\mathrm{mm}$ and air temperature in ${ }^{\circ} \mathrm{C}$ for 2015 , during the growing season of the blueberry in the first year does not affect the plant. However, in subsequent years, no pruning decreased vegetative vigour. The bushes on the plantation have not been pruned since planting.

Prior to evaluating the yields of the selected varieties of blueberries, meteorological data was obtained from the measurement station located in Leszno. This station is located $20 \mathrm{~km}$ from the plantation. The average air temperature for the year and the vegetation period was calculated, as well as the precipitation in the period of study.

The work focused in particular on the years 2014, 2015 and 2016, as the first blueberry crops in the plantation were recorded during this period. The daily temperature distribution and precipitation in the vegetation period was analysed in the selected years.

The measurements and observations were:

- total weight of harvested fruits in each of the years of testing;

- total weight of harvested fruits from the bushes of each variety, in the years 2014-2016.

Based on the data of yields from the farm in the years 2014-2016, the impact of meteorological conditions was evaluated. The results are summarised in tables and graphs. The obtained data were referenced to the meteorological conditions prevailing in the years of research, during the whole year and the vegetation period.

\section{Results}

The obtained meteorological values, presented in the graphs (Figure 1, 2), concerned daily temperatures and precipitation in the period 2006-2016.

Based on the meteorological data, it was found that the year 2014 recorded the highest average air temperature of $10.3{ }^{\circ} \mathrm{C}$ whilst the lowest air temperature of $7.6^{\circ} \mathrm{C}$ was recorded in 2010. The average annual temperature of the multi-year period was $9.4^{\circ} \mathrm{C}$. The highest annual precipitation was in 2016 , with the precipitation of $760 \mathrm{~mm}$. However, the year with the lowest total precipitation of $418 \mathrm{~mm}$ turned out to be 2011. The average total annual precipitation in the multi-year period of 2006-2016 amounted to $555 \mathrm{~mm}$. 


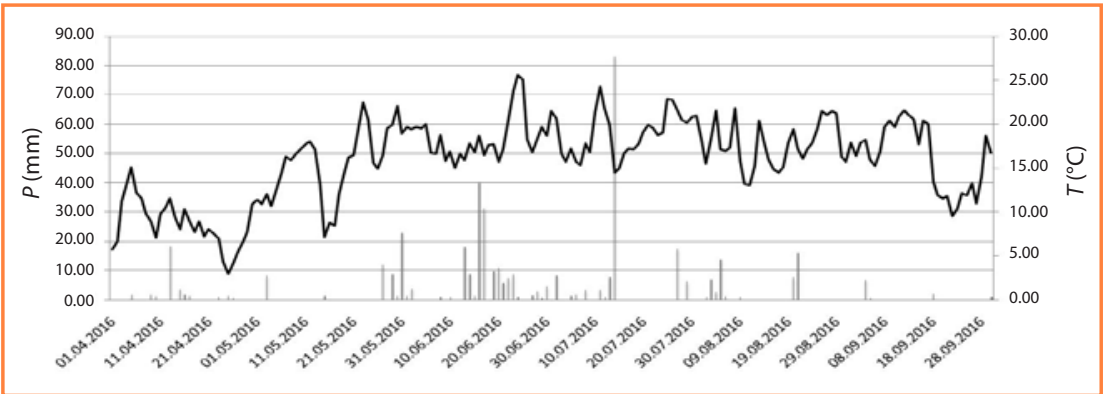

Fig. 5 Daily precipitation in $\mathrm{mm}$ and air temperature in ${ }^{\circ} \mathrm{C}$ for 2016 , during the growing season of the blueberry

After precise metrological analysis, 2014-2016 can be described as characteristic for the multi-year period. The air temperatures in the analysed period were similar to the average temperature of the multi-year period and did not differ significantly from each other. Analysing the annual precipitation levels, it can be said that 2014 was the year of a similar value to the multiyear average. The year 2015 can be defined as dry, with the total rainfall of only $484 \mathrm{~mm}$, which is by $71 \mathrm{~mm}$ lower than the average. The last year of 2016 was estimated to be wet with precipitation of $760 \mathrm{~mm}$, higher than the average of $205 \mathrm{~mm}$.
The diagrams (Figures 3, 4, 5) showed daily temperatures and precipitation during the growing season, from April to September, for the years 2014, 2015, 2016.

During the analysis of precipitation distribution in the growing season, precipitation. There were considered periods without precipitation, minimum seven days. There were five such periods in 2014, the longest was 12 days, lasting from the $11^{\text {th }}$ to $22^{\text {nd }}$ July. In 2015 , the number of precipitation free periods was seven, and the longest of them lasted for 18 days, and occurred from the $9^{\text {th }}$ to $26^{\text {th }}$ April. Despite the long drought, the total precipitation attention was paid to periods without for the month did not differ from the average monthly precipitation of $46 \mathrm{~mm}$. In the last year of 2016, eight precipitation free periods were recorded. The longest ones were from $22^{\text {nd }}$ August to $3^{\text {rd }}$ September, and from $5^{\text {th }}$ to $17^{\text {th }}$ September. The precipitation free periods, shorter than seven days, were observed at the beginning of the growing season, in April and May. However, in the months of June and July, the highest daily precipitation throughout the year was marked.

During the research, it was noticed that the average temperatures in 2014, 2015 and 2016 were similar. The blueberry yield was dependent on precipitation and changed in individual years of research. The total weight harvested in the analysed years was $256.0 \mathrm{~kg}$. In 2014, the best yields were recorded, with the total of $114.0 \mathrm{~kg}$. In the following year 2015, the yield was $83.0 \mathrm{~kg}$ and in the last year of 2016 it was only $59.0 \mathrm{~kg}$. By comparison, Figure 6 shows how the fruit weight changed during the analysed years.

These results are confirmed by studies according to Koszański, Rumasz-Rudnicka and Friedrich (2008), where he wrote about the

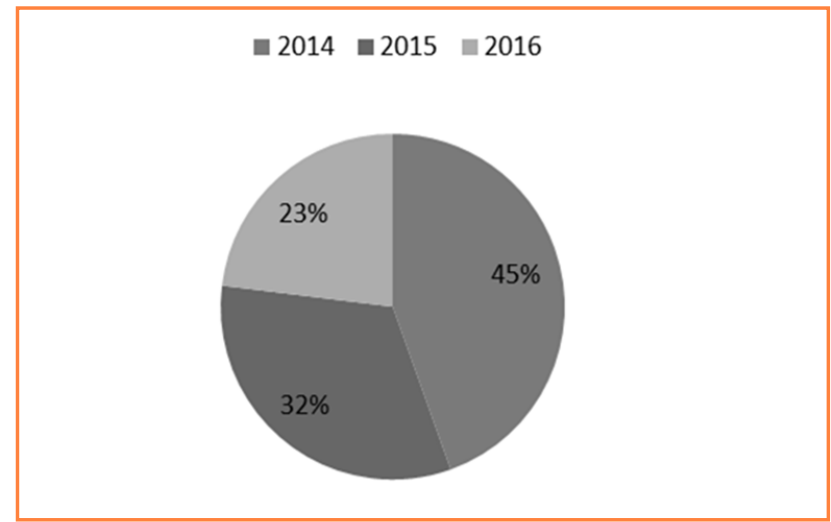

Fig. 6 Percentage of yield of tested crops in 2014-2016

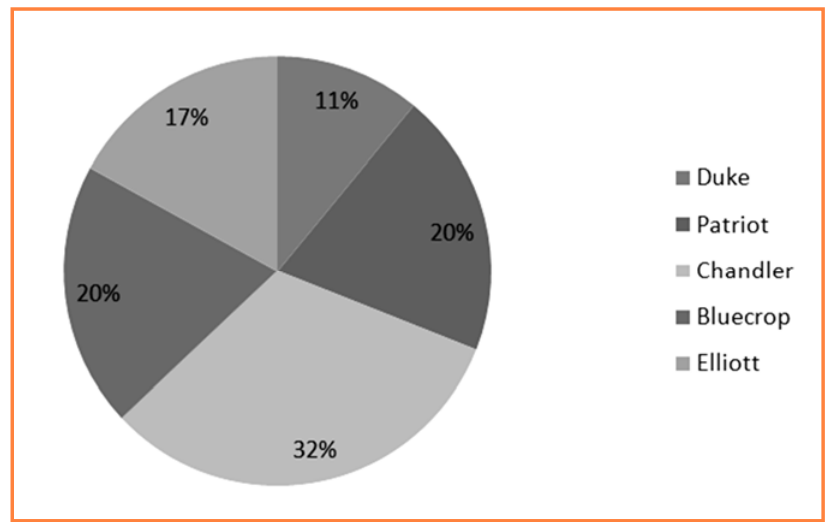

Fig. 7 Percentage of yield of selected varieties of blueberries in the examined years 2014-2016

Table 1 Average weight of fruit from one bush, each variety in the analysed years 2014-2016

\begin{tabular}{|l||c|c|c|c|}
\hline \multicolumn{1}{|l|}{ Variety } & \multicolumn{4}{|c|}{ Average weight of the fruits per bush in kg } \\
\cline { 2 - 5 } & $\mathbf{2 0 1 4}$ & $\mathbf{2 0 1 5}$ & $\mathbf{2 0 1 6}$ & average \\
\hline \multirow{2}{*}{ Duke } & 1.0 & 0.8 & 0.4 & 0.8 \\
\hline Patriot & 1.0 & 0.7 & 0.5 & 0.7 \\
\hline Chandler & 2.5 & 1.7 & 1.3 & 1.8 \\
\hline Bluecrop & 1.5 & 0.9 & 0.9 & 1.1 \\
\hline Elliott & 1.6 & 1.6 & 0.8 & 1.3 \\
\hline
\end{tabular}


optimum soil moisture for cultivation in order to increase the yield.

The variety that yielded the best was Chandler, whose fruit accounted for as much as $32 \%$ of all crops, and the worst yield was produced by Duke. Patriot, Bluecrop and Elliott were comparable. The graph (Figure 7) shows the percentage of fruit weight of each variety.

Also, the yield from individual bushes of each variety was evaluated, in relation to the examined years 2014-2016 (Table 1). In the analysed period of 2014-2016, the variety with the highest crop from one bush was Chandler, with the average weight of $1.8 \mathrm{~kg}$ of fruits. The Patriot variety gave the lowest yield from a single bush, only $0.7 \mathrm{~kg}$.

\section{Conclusions}

The study evaluated the impact of weather conditions in western Poland on crops of five selected varieties of blueberries in 2014-2016. As a result of the research, the following conclusions were obtained:

- The best yields (114.0 kg) were recorded in 2014, with regular distribution of precipitation during the growing season. In 2015, during the growing season, the precipitation was by $92 \mathrm{~mm}$ lower than in 2014, and the yield decreased by $27 \%$. In 2016 , the yield was by $48 \%$ lower than the yield in 2014. This is the consequence of the occurrence of precipitation-free periods in the growing season.

- The high yield of blueberries was caused by the quantity and distribution of precipitation in the growing season.

- The study of the total weight of harvested fruits in 20142016 showed that the worst yield was given by Duke and the best by Chandler.

- Analysis of the mass of harvested fruits per bush of blueberry showed that the worst crop was Patriot and the best one was Chandler.

\section{References}

BOKWA, A. - SKOWERA, B. 2009. Występowanie ekstremalnych warunków pluwialnych w Krakowie i okolicy w latach 1971-2005. In Acta Agrophysica, vol. 13, 2009, no. 2, pp. 299-310.

ECK, P. 1988. Blueberry science. New Brunswick : Rutgers Univ. Press, 1988, $284 \mathrm{p}$.

KAISER, C. - ERNST, M. 2014. Highbush blueberries. Cooperative extension service University of Kentucky College of agriculture, food and environment, 2014.

KOSZAŃSKI, Z. - RUMASZ-RUDNICKA, E. - FRIEDRICH, S. 2008. Wpływ nawadniania i nawożenia NPK na budowę anatomiczną i morfologiczną oraz plonowanie borówki wysokiej. In Acta Agrophysica, vol. 11, 2008, no. 3, pp. 677-684.

KOVALESKI, A.P. - WILLIAMSON, J.G. - CASAMALI, B. - DARNELL, R.L. 2015. Effects of Timing and Intensity of Summer Pruning on Vegetative Traits of Two Southern Highbush Blueberry Cultivars. In Hortscience, vol. 50, 2015, no. 1, pp. 68-73.

KRZEWIŃSKA, D. - SMOLARZ, K. - TRYNGIEL-GAĆ, A. 2009. Porównanie kilku odmian borówki wysokiej i półwysokiej. In Zeszyty naukowe Instytutu Sadownictwa i Kwiaciarstwa, Tom 17 (20909), 2009, pp. 5-16.

PERRIER, C. - MINGEAU, M. - AMEGLIO, T. - FERREIRA, M.I. - JONES, H.G. 2000. Effects of water stress on transpiration, radial growth and yield in highbush blueberry. In Acta Hort., vol. 537, 2000, no. 2, pp. 923-928.

PLISZKA, K. 2002. Borówka wysoka. Państwowe Wydawnictwo Rolnicze i Leśne.

SCHÖNTHALER, J. - BIENIASZ, M. - ŚCIBISZ, K. - MICHALSKI, P. - BULER, Z. - ŁABANOWSKA, B. - PIOTROWSKI, W. 2015. Nowe możliwości w produkcji owoców miękkich. In Centrum Doradztwa Rolniczego w Brwinowie Oddział w Radomiu, 2015.

SMOLARZ, K. 2008. Borówka wysoka.

WOŚ, A. 1995. Zarys klimatu Polski. Poznań : Bogucki wydawnictwo naukowe, 1995. 